\title{
Original Article \\ The interactions of disability and impairment
}

\author{
Edmund Coleman-Fountain and Janice McLaughlin* \\ Policy, Ethics and Life Sciences Research Centre (PEALS), Newcastle University, \\ 4th Floor Claremont Bridge Building, Newcastle upon Tyne, NE1 7RU, UK. \\ E-mails: edmund.coleman-fountain@ncl.ac.uk; janice.mclaughlin@ncl.ac.uk \\ *Corresponding author.
}

\begin{abstract}
Theoretical work on disability is going through an expansive period, built on the growing recognition of disability studies as a discipline and out of the political and analytical push to bring disability into a prominent position within accounts of the intersecting social categories that shape people's lives. A current debate within critical disability studies is whether that study should include impairment and embodiment within its focus. This article argues it should and does so by drawing from symbolic interactionism and embodiment literatures in order to explore how differences in what bodies can do - defined as impairments - come to play a role in how people make sense of themselves through social interaction. We argue that these everyday interactions and the stories we tell within them and about them are important spaces and narratives through which impairment and disability are produced. Interactions and stories are significant both in how they are shaped by wider social norms, collective stories and institutional processes, and also how they at times can provide points of resistance and challenges to such norms, stories and institutions. Therefore, the significance of impairment and interaction is the role they play in both informing self-identity and also broader dynamics of power and inequality.
\end{abstract}

Social Theory \& Health (2013) 11, 133-150. doi:10.1057/sth.2012.21;

published online 14 November 2012

Keywords: symbolic interactionism; disability studies; embodiment; impairment; stories; medical sociology

The online version of this article is available Open Access

\section{The Interactions of Disability and Impairment: Stories of Different Embodiment}

\section{Introduction}

Theoretical work on disability is going through an expansive period, built on the growing recognition of disability studies as a discipline and out of the 
political and analytical push to bring disability into a prominent position within accounts of the intersecting social categories that shape people's lives (Barnes et al, 2002; Watson et al, 2012). Disability - much like other social categories is itself contested in terms of what it signifies, what its origins are said to be, how it is produced and what its boundaries are. Disability studies, at least in the United Kingdom, was founded in the social model of disability, which makes a separation between the impairment an individual may have and the social disability an individual may experience as a result of disablism (UPIAS, 1975). It is the re-examination of the social model and the distinction it made between impairment and disability, which has been the source of much of the contemporary work within and outside disability studies exploring the nature of disability. New approaches are influenced by ideas from phenomenology (Paterson and Hughes, 1999; Scully, 2008), postmodernism (Corker and French, 1999; Tremain, 2002; Shakespeare, 2006) and queer studies (Goodley, 2011) among others. Critical disability studies is now used to signify much of this work, particularly work that is marked by an interest in embodiment, or more specifically, non-normative embodiment. Writers such as Shildrick $(2002,2009)$ are seeking to 'expose the uncertain and vulnerable nature of all forms of embodied selfhood' (Shildrick, 2012, p. 37), in order to explore the political significance of discomfort with 'non-normative morphology' (Shildrick, 2012, p. 39) for those whose body shape or capability falls outside the societal imaginary. This shift has not been welcomed by all working in disability studies; it is presented as irrelevant, academic, dangerous and of little use. This critique has been heightened by the current context of economic uncertainty, the dismantling of welfare rights and the increase in hate crimes against disabled people (Barnes, 2012).

Our article makes an argument for a continued interest in embodiment in work concerned with disability. Our case is that a particular approach to exploring embodiment, one overlapping with, while also somewhat different from that currently represented in the work of critical disability studies, can enable a richer appreciation of how impairment becomes disability: that is, why is it that some differences in the capacities and appearance of some bodies become significant in people's social position in the world - often to their detriment. To do so, we are drawing from symbolic interactionist ideas, those that have a concern both with accounts of the body and the body itself. We advocate the inclusion of symbolic interactionism within the repertoire of critical disability studies because through it we can attend to the ways in which subjective experiences of the body emerge in the interplay between physical and cultural interaction. Interactionism opens up a much-needed concern with how individual actors interpret social situations and their embodied positions within them, 
recognising the different abilities that bodies allow while not reducing disability to a property of the person.

From the beginning, it is important to say that our focus on embodiment should not be seen as equating to an interest only in physical impairment. Instead, a range of differences in cognitive development, behaviour and learning style that are considered to be impairments also mark themselves out in different forms of bodily expression and movement - which become socially significant in interactions and in processes of marginalisation and exclusion. We are interested in how a variety of bodies are lived and thought of as impaired and how that leads to particular interactional dynamics and hierarchical social positionings.

This takes us to the heart of what we wish to explore: the significance of social interaction in how bodies are made sense of, and the significance of bodies in how social interaction occurs. This implies an interest in several things: everyday encounters, individual identities, bodies and emotions and language. While we will initially spend some time exploring the components of interaction at this micro level, what we will also do is show how these interactions play a role in larger scale dynamics of power, regulation, marginalisation and discrimination. We begin the article by mapping out Goffman's Stigma, setting out how disability as a mark of difference sets people out as 'other' to the 'normal'. The power of micro-level interaction is subsequently understood as based in both the materiality of bodies and in the stories that give meaning to those bodies. We then explore the institutionalisation of impaired bodies, asking how contemporary understandings of different impairments become embedded in institutions such as welfare and become significant in framing the lives of disabled people. We conclude by addressing issues of power, and the potential opened up by our approach to challenge different and 'damaging' narratives of embodiment through the telling of new stories of impairment and disability.

\section{Framing Bodily Difference: Goffman's Study of Stigma}

Symbolic interactionism has a long history within sociology. Its roots are in pragmatism and phenomenology, and it grew from the work of a group of sociologists known as the Chicago School in the early part of the twentieth century (Blumer, 1937, 1969). From its beginning, it has been interested in both the dynamics of social encounters and the creation of categories of 'deviant' populations through those encounters. Disability has been a long-term interest, both because symbolic interactionists argue that it unsettles the norms of social encounters - Davis (1961) argued it produced 'sticky encounters' - and because 
in doing so disability is then framed as a form of deviancy (Becker, 1973). Much of interactionism's focus has been on how the disabled person seeks to avoid the social penalty of being framed as deviant by managing their disability so that the disruption is minimised (Sheehan, 1968, 1970; Lemert, 1970). One of the most sustained accounts of disability from this perspective is that by Erving Goffman, a sociologist trained in the traditions of the Chicago School in the period immediately following the Second World War. His classic text Stigma was a major contribution to the development of a sociology of deviance and his broader analysis of social interaction has been a major influence on the development of much contemporary sociology (Smith, 2000). Within disability studies his legacy, derived primarily from his work on stigma, has been an appreciation of how assumptions of 'normality' shape social responses to impaired bodies (Wendell, 1996; Titchkosky, 2000). For Goffman, impairment, understood primarily as a form of physical difference, is not inherently stigmatising but becomes so in interaction whereby the meanings generated between people get attributed to impairments that break with perceived bodily norms. As Smith (2000, p. 85) states, Goffman was not concerned with the fact of stigma per se but how different contexts construct different things as stigmas. A difference becomes a stigma when it is deemed by others to be discrediting, and as it creates a discrepancy between a person's assumed 'virtual' social identity and their 'actual' social identity (Goffman, 1990 [1963], p. 12).

Goffman's analysis of stigma has proved useful in exploring the power relations embedded in cultural constructions of 'normal' embodiment. The 'normal', Goffman (1990 [1963], p. 15) argues, is a prized cultural status ascribed to those 'who do not depart negatively from the particular expectations at issue'. The corporeal expectations that govern a situation are established in what Goffman would later describe as 'frames' - internalised social expectations that structure how events, or 'doings', are apprehended and understood. Cultural scenarios, he suggests, are made sense of through 'schemas of interpretation' (Goffman, 1974, p. 21). In Stigma, Goffman suggests that the 'normal' prefigures expectations a person has of the body. These expectations are not necessarily universal but shift depending on an individual's experience of different forms of embodiment, ${ }^{1}$ as is implicit in Goffman's (1990 [1963], p. 46) description of the 'own' and the 'wise'. For instance (and taking care to acknowledge Goffman's easy use of his own terminology), he gives the example of the family of a 'congenitally stigmatised child' who protect that child from 'belittling definitions' so as to engender her or his own 'normal' sense of self. Contemporary work continues to draw on Goffman in understanding the management of social discomfort done by disabled people and their carers (de Klerk and Ampousah, 2003; Anderson, 2009). McLaughlin and colleagues have explored how the families of disabled children manage the negative 
responses of others towards their children (McLaughlin and Goodley, 2008; McLaughlin and Clavering, 2012). Likewise, Scully explores the 'hidden labour' disabled people undertake to negotiate the discomfort of others so they may make their way in interactions:

This 'dealing with', which entails controlling one's self-presentation, identifying what the other person needs to know or wants to feel, evaluating which strategies are needed and implementing them, producing the required responses in turn, and so on, costs significant physical and psychological energy. (Scully, 2010, p. 31)

Acton and Hird draw explicitly from Goffman to explore the difficulties faced by those who stutter in social interactions, and argue that drawing a symbolic interactionist approach into a sociological analysis of stuttering allows us to produce 'examples of the micro-processes though which individuals create and maintain the differentiation between "normal" and "stigmatized" (Acton and Hird, 2004, p. 509).

Drawing from the work of Goffman and other interactionists, what we want to explore is how particular kinds of embodiment get framed as different, by whom and in what contexts, and what the implications of those framings are, stigmatising or otherwise. Asking such questions sets disability up as at once a personal issue and a political one (Williams, 2001) and, in so doing, opens up ways for disrupting or reframing stigmatising accounts of different embodiment. However, in proposing an interactionist approach, we come across a puzzle that various writers propose interactionism cannot resolve: if meanings and identities emerge in interaction, and interactions are happening all the time in everyday encounters of varying size and complexity, how do patterns of interaction, selfhood and embodiment develop that appear to have the power to delegitimise other interactions, shut down what is possible to imagine and deny validity to alternative ways of being and acting? Interactionists like Goffman have been criticised by disability studies scholars (Oliver, 1990; Abberley, 1993; Wendell, 1996) and others (Bourdieu, 1989; Reynolds, 1993; Longmore, 1998) for politically naïve understandings of the social and material contexts that inform the interactions they have studied. The overall suspicion is that interactionists are oblivious to macro-structural issues due to their privileging of micro relations that constitute 'subjective' everyday life. In addition, the accounts of self-management produced by symbolic interactionist approaches either implicitly or explicitly run the risk of validating the status quo by implying that there is agency involved in how disabled people make interactions possible via their own performance and skill. The cost and labour such performances require and the inequality embedded in who must adapt to the norms of others is given significantly less attention (Scully, 2010). 
We propose two ways of exploring the puzzle that explain why it is analytically valuable and politically useful to include an interest in social interaction when seeking to understand the inequalities produced by disability as a social category: (i) the importance of examining the materiality of the body in interaction and exploring under what conditions that materiality is produced as impaired; and (ii) how norms of interaction are further secured via the accounts produced by cultural narratives and institutional processes, which sustain the inequalities embedded in how performances are judged and carried out.

\section{The Matter of Impairment}

Poststructuralist accounts, including those within critical disability studies, rightly emphasise the processes of inscribing meaning onto bodies as an important element of interaction, and, consequently, our subjective experience of our bodies (Crossley, 1996). However, where we differ from some of the accounts of embodiment and disability coming to the fore in critical disability studies is wishing to hold on to the matter of impairment and the body. The significance of post-structuralist ideas to the development of critical disability studies leads to a concentration on accounts of, rather than engagement with, the body itself. Echoing Scully (2008), we think that it is important to retain some distinction between bodily difference, impairment and disability, because we want to maintain that the specifics of differences in what a body is and can do matter. This view is in contrast to other writers such as Goodley $(2001,2011)$ for whom impairment has no actual correspondence to material reality:

To talk of the 'brute facts' of impaired or normal bodies evokes a biology that has already been constructed. Regulatory norms hail subjects to assume positions .... The body is not some entity prior to signification: it has already been through a process of signification. (Goodley, 2011, p. 119)

Goodley's view is that impairment is not an intrinsic property of the body; instead it is produced by categories of diagnosis and labelling. Categories such as Down's syndrome or other genetic conditions have no neutral meaning beyond the medical processes that produce them as real. We follow to some degree, particularly in how categories of medical definition are vital factors in shaping and informing social interaction. This is seen very clearly in the growing scope of genetics and its ability to produce 'ontologically disputed borderline forms of disease' (Buchbinder and Timmermans, 2011, p. 57). In such contexts, it seems possible that the actual material of the body hardly matters. However, where we move away from Goodley is to argue that it seems 
much less likely that bodies never matter. Even in the case of genetic screening, the interactions involved in diagnosis and communication of findings do not remain at the biochemical; for example, in new born screening or children undergoing genetic testing, parents make sense of genetic versions of their child, alongside the presence of the actual child, both in the consultations with geneticists and in everyday life (McLaughlin and Clavering, 2012).

Without the associations made between particular bodies and inferences such as healthy, attractive, child, adult, gay, straight, such categories could not be made secure and socially significant. They become secure and socially significant through the influence they have on what actual bodies do and how they are read in interaction. Feminist social geographers have long been interested in the gendered dynamics of public space, enacted in the different ways in which men and women 'take up' that space around them and through it create boundaries of belonging and exclusion (McDowell, 1983; Davies, 2003). Our own approach takes into account the materiality of the body as a part of social encounters. The way in which bodies look and function are significant in informing social interactions and are fundamental in deciding how bodies and persons 'fit' within normative frameworks of understanding. As we see with Olympic hopefuls such as Caster Semenya and Oscar Pistorius, ${ }^{2}$ for example, the ways in which bodies are framed as 'normal' or 'other' draws on the body's physicality as it is read in social situations.

Poststructuralist analyses such as that offered by Goodley and Shildrick, by emphasising the cultural processes that give meaning to that body - including meanings that disable - without keeping hold of the specifics of the body itself, miss three important aspects of how those meanings become possible and maintained. First, some forms of bodily difference are easier to frame as particular impairments than others. Medicine may be powerful but it would struggle to have people accept an explanation of an inability to walk as a symptom of deafness when the person in question is a double amputee. This may seem a facile point, but we do not believe that it is. Both processes of diagnosis and living must work with bodies that exist, implying that not all meanings are possible - certainly not as factors in social interaction and producers of inequality. As Mol (2002, p. 24) points out ' ... what is needed, indeed indispensable for clinical diagnosis, is that there be a patient-body'. This is an important limit on the power that medicine can maintain in the production of impairment as well as disability. As such, when we suggest that biopower needs a body we are recognising the processes by which meaning gets invested in the body, but in such a way that makes use of that body's capacities. To talk of a visual impairment thus implies something about the capacity of a body to see. For this reason, we hold on to impairment as based in materiality, including the physical and emotional pain associated with forms of difference, and 
experiences of limitation as the body reaches into the world and comes up against it.

The second reason to keep hold of the body is in order to explore cultural hierarchies of meaning and stigma that are inscribed in and to different kinds of bodily difference. Different kinds of impairment lead to different levels of prejudice because of the different affects they have on how the body looks. Body appearance becomes a factor in prejudice through the powerful social norms that equate values of the grotesque as opposed to beauty (of both soul and body). There is a long history of associations between unusual physical features and evil (Russo, 1995; Shildrick, 2002). But it is not any bodily difference that gets equated with such folk devils. How such readings become ascribed to particular bodies and not to others is an important aspect in the production of hierarchies of prejudice towards specific kinds of impairment. For example, the female 'cute' looking Down's syndrome child is much more likely to be a symbol of charitable giving and pity than the 45-year-old man with Down's syndrome (Riley, 2005). Research on the Paralympics has highlighted how media coverage often centres on the male, muscular paraplegic (usually acquired) playing sports such as basketball, in comparison with the male adult with cerebral palsy who competes in the shot put, who has difficulties speaking 'normally', drools and has muscle spasms they cannot control (Hardin and Hardin, 2008).

The third reason for keeping hold of the body is to retain an interest in what people do with their bodies as part of their participation in social interaction and the development and maintenance of a self. On a face-to-face level, it seems reasonable to acknowledge that there are forms of limitation in what the body can do that can make interaction at least more tricky (or sticky going back to Davis's (1961) language) when contrasted with what we perceive others to be able to do or not. As Mol (2002, p. 15) notes 'Living with legs that hurt when walking does not only invite a person to make sense and give meaning to his or her situation, but it is also a practical matter'. For example, Scully (2008, p. 16), who has a hearing impairment, finds that she struggles when interacting with men whose beards obscure their faces, and French (1993, p. 18) highlights how her inability, due to having a visual impairment, to read embodied non-verbal clues can cause difficulties. Various writers within disability studies would acknowledge that this is true, but would argue that it is either conceptually or politically irrelevant, it is what society does or does not do by providing interpreters, technological tools, personal assistants and so on that matters and which would alleviate the significance of those limitations.

Our argument is that it is not enough to respond to the practical difficulties these interactions create. The emotional labour in both responding to the difficulties an impairment may create and the response of those you are in 
interaction with is not resolved by the production of practical solutions. The work of bringing those solutions into the interaction must be done by those present, in particular the often 'hidden labour' of the disabled person who is managing the discomfort and lack of care of others (Scully, 2010). For example, classroom assistants are an important practical resource in supporting disabled children to participate in mainstream education. However, several studies have shown that their presence in a classroom can amplify how a child or children are differentiated and marginalised from those around them (Holt, 2004). Only an approach exploring the dynamics of the classroom space, including the interaction of bodies as well as words, can capture how a classroom assistant can become a factor in the production of othering. Understanding how that form of interaction develops, as opposed to one marked by inclusion and diversity, also involves incorporating the broader social, material and institutional contexts that inform its dynamic. For example, the classroom context of the assistant supporting the disabled child is informed by the ways in which 'special needs' have been institutionalised within education statements, by the ways in which schools tell stories about success and achievement in the context of school league tables that focus on exam attainment, and by the ways in which the infrastructure of many schools remains 'unfit for purpose', particularly to a world of inclusive practice and access. This point takes us towards the second part of answering the puzzle of the relationship between interactionism and power: the stories that inform bodies in interaction.

\section{Stories of the Body}

We assert that everyday interactions draw from and feed into wider collective negotiations that influence dynamics of power at both the individual and collective level. The model we use in supporting this claim is the notion of storytelling. In interactionist sociology, storytelling has emerged as a key metaphor for understanding the ways in which social life is organised in narrative form. Whereas other narrative approaches have typically focussed on form, symbolic interactionism in contrast explores the embodied and organisational practice of storytelling (Plummer, 1995). As such, it pays specific attention to the contexts and interactions in which stories are told, as well as the specifics of stories themselves, providing 'analytic purchase on enduring questions about authority, inequality, conflict and change’ (Polletta et al, 2011, p. 111). Stories operate, it is claimed, as 'social and cultural resources through which people engage in ... sense-making' (Lawler, 2008, p. 32). This notion has been utilised by writers such as Hammack (2008) who draws on symbolic interactionism to describe the way in which personal identities emerge from 'master narratives', 
a process that establishes a link between self and society. How we make sense of ourselves is linked to both the bodies we have and also draws on and recasts stories about bodies like ours that circulate in wider society. For example, work by feminist sociologists such as Skeggs $(1997,2001)$ and Lawler (2012) have detailed the class politics of taste that are played in embodied practices and readings of people said to be in and out of place.

Different stories abound about the body and how it should function and look. For instance, the emphasis on health and fitness in American popular culture, as evinced in television programmes such as The Biggest Loser, reflects a dominant cultural narrative in which losing weight is considered a path to personal salvation. The prizing of particular standards of health and beauty in such accounts becomes an organising principle around which individuals make sense of their own bodies, lives and identities through the telling of personal stories of diet, exercise and weight gain and loss (Edgely, 2006; Silk et al, 2011). Stories of the athletic body, embedded in accounts of sporting achievement, have also been shown to provide a means for young men to perform their gender by embodying culturally normative views of what it is to be male, even in times of a so-called 'crisis' of masculinity (Naess, 2001). In cases where such bodies change due, for instance, to spinal cord injury, stories are drawn on that reframe the once sporting body in ways that call in to question prior gendered self-understandings (Sparkes and Smith, 2002). In each of these cases, powerful narratives about health, gender and body intersect to frame individual's accounts of themselves. Therefore, wider understandings are embedded within the situations within which people come to tell their own stories (Frank, 1995; Plummer, 1995; Hammack, 2011). Stories in this respect are highly normative; they frame the ways in which people make sense of their social worlds and the identities that are available to them within it. They give form to interactions by establishing the roles, plots and settings that individuals act out in their everyday lives (Maines, 1993). The 'normal' body is a cultural text transmitted through storytelling that has significant implications for how we approach our own embodiment. Such stories and narratives mean that interactions never begin in isolation - certain forms of interaction and reading are more possible than others and influence how people enact those interactions, including whether to conform to or resist them.

An interest in stories orients us to the intersections between narratives of self and the collective, and to the organisational and cultural contexts in which individuals fashion those narratives, including the scripts and material resources provided within those contexts. It also enables us to address sociological questions of power, asking how particular stories get authorised, and by who, and the implications of that power in shaping how people position themselves within their wider social milieu. Symbolic interactionism does not 
(necessarily) ignore structures of power; rather we use it in order to understand how the possibilities of constructing and telling stories are played out, as Plummer (1995, p. 27) puts it, in a hierarchical 'flow of power ... both personal power that allows for stories to be told or withheld; and social power which creates spaces or closes down spaces for stories to be voiced'. As such, this way of thinking about and studying stories recognises that power differences exist in society, differences that enable or constrain the extent to which stories can get told, and that because of this people occupy different hierarchical positions in the negotiated order (Maines, 1977).

Nevertheless, many disability theorists, outside of critical disability studies, would see such attempts 'to present a negotiated social order', as deflecting 'attention away from the links between micro-level attitudes and practices and the wider social structure and power relations' (Barnes and Mercer, 2010, p. 56). However, our approach aims to avoid that problem by stressing the significance of institutions as key story tellers and framers of acceptable and unacceptable bodies (Holstein and Gubrium, 2000). Stories are granted greater validity by the way they are secured through institutional processes and structures that give shape to everyday interactions by, for example, defining which stories are legal, which the state will support via welfare provision, and which will be celebrated as good or moral in culture and creative expression. They are also secured via a cycle of material resource and reward that enable some to dictate the stories that enable and justify inequalities in society. The formal power of material resources, policy, law and institutional structure, as well as the informal power of social mores influence the processes by which people 'become' who they are through creating the different positions people take and find themselves in, the roles and identities they may adopt, and shaping people's own internal, including emotional, perception of themselves.

The clearest example we see at the moment of the political significance and danger of institutionalised stories in the United Kingdom relates to the current retrenchment of welfare rights. From the beginning of the current focus on reducing the welfare budget, disabled people have been targeted to lose benefits such as Disability Living Allowance (to become Personal Independence Payment with significant limitations in comparison) and Incapacity Benefit (the Employment and Support Allowance is already being phased in, again with significantly reduced entitlement). These significant changes to the rights available to disabled people are secured in governmental stories, rearticulated in the media and validated in biomedical framings. The institutionalised stories circulating around welfare change place the disabled body at its centre, telling a medicalised narrative of which bodies (the vast majority) are fit for work, how bodies that are not can be made fit for work, and how only through work will such bodies take on value and purpose. Such narratives are not new, any 
history of welfare change will chart the ways in which particular subjects of welfare are framed as undeserving, drawing on embodied stories that are classed, gendered, racialised and disablist (Fraser and Gordon, 1994, 1997; Lister, 1997). One of the main ways in which disability campaigners are challenging these institutionalised stories is to use social media to circulate their own stories of those refused benefits as 'counter stories' to the official rhetoric.

What does an emphasis on such dominant narratives mean for our other argument that the materiality of bodies matter? How do we bring these two parts of the puzzle together? Our argument is that what makes some meanings convincing is both how they correspond with broader social stories and narratives that make interaction possible (having no legs means one is both impaired - given the norm that most people will have legs and a society designed around that norm - and also someone to be seen as tragic or heroic), and the actual body and its potential within that interaction. While language and discourse matters, so does matter itself. It is not incidental which body is read as healthy/unhealthy, able/unable, attractive/ugly. While bodies are not intrinsically any of these things, the establishment of such standards are marked on actual bodies whose shape, movement and emotional connection is changed by them.

What we want to stress is that both impairment and disability are emergent in interaction, rather than an essential aspect of the person. Bodies can be different in numerous ways, and many of those differences will not be significant (Scully, 2008). An important aspect of what makes something a notable difference however is how it manifests itself as a socially salient issue within an interaction. What makes something 'notable' is based on the interplay between the embodied, emotive and linguistic dynamics of a specific situation and the broader social narratives, scripts and modes of recognition, which inform how those present come to that interaction, participate in it and produce meaning from it. The meanings attached to difference, as we learn from symbolic interactionism, are not inherent, but are a product of what occurs in social environments and in the company of others. How a society constructs norms of embodiment and responds to people that fall out with those norms raises questions about what it means to live with a different kind of body. The power of coding bodies as 'other' to the normal emerges in how certain embodiments are privileged, and the effects of that privileging on how bodies are perceived.

Tales of the 'normal' body that exclude impaired embodiments create space for further stories of stigma and 'otherness,' while closing down opportunities for stories that appreciate impairment (Shakespeare, 1994). Stories are part of the contexts that create the inequality within the 'structure of relationality' (Scully, 2010, p. 33) embedded in interactions between the disabled and the 
non-disabled that require the disabled to perform in certain ways in order to avoid stigmatisation. The question for Shildrick is what is the political significance of the continued circulation of versions of embodiment that deny the postive possibilities within non-normative forms of embodiment. Her argument, and one we agree with and believe research taking a symbolic interactionist approach can uncover, is that the multiple levels of discrmination disabled people face relate to the ways in which their embodiment fractures the myth of the autonomous, independent self as the ideal. The valarization of this ideal requires the framing of what cannot fit within it as unwanted, unwelcome and unfit, an act that is 'a violent imposition of epistemic and/or material power' (Shildrick, 2012, p. 34). Without the imposition of such stories, the division itself between the disabled and non-disabled would not make sense. Deconstructing the powerful imaginery of autonomous self-hood - something which 'non-normative morphology' has the potential to do - would make evident the 'vulnerable nature of all forms of embodied selfhood' (Shildrick, 2012, p. 37).

Stories require bodies to enact them in order to become real, repeated and understood. This reliance on bodies as well as explaining how stories are secured also points to the weaknesses inherint in their operation. Stories are contestable, and while some stigmatising narratives do achieve a dominant cultural position, that position is by no means guaranteed, new stories can emerge from disabled people themselves (Shakespeare, 1996). Crucially, actual bodies can become sources and objects of challenge in the way people make use of them - creatively and practically - to challenge norms associated with body shape, look, mobility and dexterity, and to offer accounts of disability that are validating. The direct action of some disabled groups which turn wheelchairs into barriers that mean the able bodied cannot go about their business is just one example of this. The growing presence of disability arts is another. Some parrallels may be drawn with sexuality studies. Just as gay and lesbian writers have argued that biomedical processes of labelling contributed to construction of the modern homosexual (Plummer, 1981), so too did the deployment of categories of disability contribute to the making of the disabled person (Blaxter, 1976). And just as we see with the gay rights movement, the emergence of disability activism has sought to wrest definitions of disability away from biomedicine by forming new stories of oppression and discrimination (Oliver, 1990) as well as of value and pride (Morris, 1991; Wendell, 1996). It is these dynamics in which we are interested. The question of power moves from being one of oppressive social structures to the definitional processes that underpin what it means to be disabled. It is our contention that exploring stories of bodily difference is an important means of understanding processes of deligitimation and ways in which they may be challenged. 


\section{Conclusion}

Drawing all these arguments together, disability can be thought of as an emergent and variable property, which arises out of the interaction between a heterogeneous range of impairments, as well as other characteristics (age, gender, ethnicity and so on), within the presence of social stories and norms embedded and validated in material resources and institutional practices (Mitra, 2006). This framing seeks to acknowledge structural constraints and enablers, desires and the materiality of the body, including a host of impairments, that may arise at any time, and which cannot be conflated with one another (Breckenridge and Vogler, 2001). It raises questions about self and embodiment particularly where it shifts a focus away from a universalistic notion of oppression to the contextualised aspirations of the embodied actor. In this sense, interactionism allows for an engagement with impairment no longer trapped in notions of tragedy and suffering. Through it, we can explore how people's sense making of their bodies is productive, rather than thinking of impairment as something to be overcome in order to retain/gain a positive sense of self.

A concern with impairment in interaction may on the one hand be about the experience of limitation, but it may also be about how impairments can be productive via the creative and expressive ways in which people bring their different bodies into interaction to challenge presumptions that they are tragic or heroic. Such micro dynamics of enhancement deny power to dominant stories that position someone as disabled. They produce counter narratives to those that seek to deny that person the expressive space to define their self and identity in the context of bodies which cannot do certain things, but which can do so many others. In characterising impairment in such a way then we assume a practical and creative orientation to the social worlds in which people are embedded and the challenges that come with that. This take on symbolic interactionism thus 'emphasizes human beings as active and creative agents [and] a human world that both shapes the doings of people and is fashioned by the doings of people' (Waskul and Vannini, 2006, p. 3). Orientations to social worlds are not set in stone; instead, they are negotiated and interpreted by people who are 'active agents in the production of knowledge' (Kruse, 2010, p. 185). This takes us to a final benefit in bringing a focus of embodiment and interaction into the analysis of disability: appreciation of forms of challenge and resistance.

\section{Notes}

1 Goffman (1974, p. 37) makes this further clear in Frame Analysis when he asserts the need for a multiplicity of frameworks to make sense of the body, which is 'constantly present as a resource'.

(C) 2013 Macmillan Publishers Ltd. 1477-8211 Social Theory \& Health Vol. 11, 2, 133-150 
2 Caster Semenya is a South African athlete whose gender has been contested. Various hormone tests have been used to establish her 'correct' gender in order to clarify whether she is entitled to compete as a female athlete. Establishing her 'correct' gender has been thwarted by the ambiguity of what can categorically prove whether one is male or female. Oscar Pistorius, also a South African athlete, is a double amputee who runs with the aid of sophisticated prosthetic limbs (or blades). He has generated significant debate due to his wish to run in the Olympics as well as the Paralympics (he has been selected to run in the 4 by $400 \mathrm{~m}$ relay for the Olympics in 2012). What is contested is whether the technology that replaces his missing limbs is a form of enhancement (akin to drugs), which is an unfair advantage on other competitors.

\section{References}

Abberley, P. (1993) Disabled people and 'normality'. In: J. Swain, V. Finkelstein, S. French and M. Oliver (eds.) Disabling Barriers - Enabling Environments. London: Sage, pp. 107-115.

Acton, C. and Hird, M. (2004) Towards a sociology of stammering. Sociology 38(3): 495-513.

Anderson, D. (2009) Adolescent girls' involvement in disability sport: Implications for identity development. Journal of Sport \& Social Issues 33(4): 427-449.

Barnes, C. (2012) Understanding the social model of disability: Past, present and future. In: N. Watson, A. Roulstone and C. Thomas (eds.) Routledge Handbook of Disability Studies. London: Routledge, pp. 12-29.

Barnes, C. and Mercer, G. (2010) Exploring Disability. Cambridge, UK: Polity Press.

Barnes, C., Oliver, M. and Barton, L. (eds.) (2002) Disability Studies Today. Cambridge, UK: Polity Press in association with Blackwell Publishers.

Becker, H.S. (1973) Outsiders: Studies in the Sociology of Deviance. New York: The Free Press.

Blaxter, M. (1976) The Meaning of Disability. London: Heinemann.

Blumer, H. (1937) Social psychology. In: E.P. Schmidt (ed.) Man and Society. Englewood Cliffs, NJ: Prentice-Hall, pp. 144-198.

Blumer, H. (1969) Symbolic Interactionism: Perspective and Method. Berkeley, CA: University of California Press.

Bourdieu, P. (1989) Social space and symbolic power. Sociological Theory 7(1): 14-25.

Breckenridge, C.A. and Vogler, C. (2001) The critical limits of embodiment: Disability's criticism. Public Culture 13(3): 349-357.

Buchbinder, M. and Timmermans, S. (2011) Medical technologies and the dream of the perfect newborn. Medical Anthropology Quarterly 30(1): 56-80.

Corker, M. and French, S. (eds.) (1999) Reclaiming discourse in disability studies. In: Disability Discourse. Buckingham, MD: Open University Press, pp. 1-14.

Crossley, N. (1996) Body-subject/body-power: Agency, inscription and control in Foucault and Merleau-Ponty. Body \& Society 2(2): 99-116.

Davies, K. (2003) The body and doing gender: The relations between doctors and nurses in hospital work. Sociology of Health \& Illness 25(7): 720-742.

Davis, F. (1961) Deviance disavowal: The management of strained interaction by the visually handicapped. Social Problems 9: 120-132.

de Klerk, H.M. and Ampousah, L. (2003) The physically disabled woman's experience of self. Disability and Rehabilitation 25(19): 1132-1139.

Edgely, C. (2006) The fit and healthy body: Consumer narratives and the management of postmodern corporeity. In: D.D. Waskul and P. Vannini (eds.) Body/embodiment: Symbolic Interaction And the Sociology of the Body. Aldershot, UK: Ashgate, pp. 231-246.

Frank, A.W. (1995) The Wounded Storyteller: Body, Illness, and Ethics. London: University of Chicago Press. 
Fraser, N. and Gordon, L. (1994) Dependency' demystified: Inscriptions of power in a keyword of the welfare state. Social Politics 1(1): 4-31.

Fraser, N. and Gordon, L. (1997) A genealogy of 'dependency': Tracing a keyword of the U.S. welfare state. In: N. Fraser (ed.) Justice Interruptus. London: Routledge, pp. 121-149.

French, S. (1993) Disability, impairment or something in between. In: J. Swain, V. Finkelstein, S. French and M. Oliver (eds.) Disabling Barriers - Enabling Environments. London: Sage/Open University Press, pp. 17-25.

Goffman, E. (1974) Frame Analysis: An Essay on the Organization of Experience. Cambridge, MA: Harvard University Press.

Goffman, E. (1990 [1963]) Stigma: Notes on the Management of a Spoiled Identity. London: Penguin Books.

Goodley, D. (2001) Learning difficulties', the social model of disability and impairment: Challenging epistemologies. Disability \& Society 16(2): 207-231.

Goodley, D. (2011) Disability Studies. London: Sage.

Hammack, P.L. (2008) Narrative and the cultural psychology of identity. Personality and Social Psychology Review 12(3): 222-247.

Hammack, P.L. (2011) Narrative and the Politics of Identity: The Cultural Psychology of Israeli and Palestinian Youth. Oxford: Oxford University Press.

Hardin, M. and Hardin, B. (2008) Elite wheelchair athletes relate to sports media. In: K. Gilbert and O.J. Schantz (eds.) The Paralympic Games: Empowerment Or Sideshow? Maidenhead, UK: Meyer \& Meyer, pp. 25-33.

Holstein, J.A. and Gubrium, J.F. (2000) The Self We Live By: Narrative Identity in a Postmodern World. Oxford: Oxford University Press.

Holt, L. (2004) Childhood disability and ability: (Dis)ableist geographies of mainstream primary schools. Disability Studies Quarterly 24(3), http://dsq-sds.org/article/view/506/683, accessed 28 February 2012.

Kruse, R.J. (2010) Placing little people: Dwarfism and the geographies of everyday life. In: V. Chouinard, E. Hall and R. Wilton (eds.) Towards Enabling Geographies: 'Disabled' Bodies and Minds in Society and Space. Farnham, UK: Ashgate, pp. 183-198.

Lawler, S. (2008) Stories and the social world. In: M. Pickering (ed.) Research Methods for Cultural Studies. Edinburgh, UK: Edinburgh University Press, pp. 32-50.

Lawler, S. (2012) 'Normal people': Recognition and the middle classes. In: J. McLaughlin, D. Richardson and P. Phillimore (eds.) Contesting Recognition: Culture, Identity and Citizenship. Basingstoke, UK: Palgrave Macmillan, pp. 53-73.

Lemert, E.M. (1970) Sociological perspective. In: J.G. Sheehan (ed.) Stuttering: Research and Therapy. New York: Harper \& Row, pp. 170-187.

Lister, R. (1997) Citizenship: Feminist Perspectives. Basingstoke, UK: Palgrave Macmillan.

Longmore, M.A. (1998) Symbolic interactionism and the study of sexuality. The Journal of Sex Research 35(1): 44-57.

Maines, D.R. (1977) Social organization and social structure in symbolic interactionist thought. Annual Review of Sociology 3: 235-259.

Maines, D.R. (1993) Narrative's moment and sociology's phenomena: Towards a narrative sociology. Sociological Quarterly 34(1): 17-38.

McDowell, L. (1983) Towards an understanding of the gender division of urban space. Environment and Planning D-Society \& Space 1(1): 59-72.

McLaughlin, J. and Clavering, E.K. (2012) Visualising difference, similarity and belonging in paediatric genetics. Sociology of Health and Illness 34(3): 459-474.

McLaughlin, J. and Goodley, D. (2008) Seeking and rejecting certainty: Exposing the sophisticated lifeworlds of parents of disabled babies. Sociology 42(2): 317-335.

Mitra, S. (2006) The capability approach and disability. Journal of Disability Policy Studies 16(4): 236-247. 
Mol, A. (2002) The Body Multiple: Ontology in Medical Practice. London: Duke University Press.

Morris, J. (1991) Pride Against Prejudice: Transforming Attitudes to Disability. London: The Women's Press.

Naess, F.D. (2001) Narratives about young men and masculinities in organised sport in Norway. Sport Education and Society 6(2): 125-142.

Oliver, M. (1990) The Politics of Disablement. Basingstoke, UK: Palgrave Macmillan.

Paterson, K. and Hughes, B. (1999) Disability studies and phenomenology: The carnal politics of everyday life. Disability \& Society 14(5): 597-610.

Plummer, K. (ed.) (1981) The Making of the Modern Homosexual. London: Hutchinson.

Plummer, K. (1995) Telling Sexual Stories: Power, Change and Social Worlds. London: Routledge.

Polletta, F., Chen, P.C.B., Gardner, B.G. and Motes, A. (2011) The sociology of storytelling. Annual Review of Sociology 37: 109-130.

Reynolds, L.T. (1993) Interactionism: Exposition and Critique. Lanham, MD: General Hall.

Riley, C.A. (2005) Disability and the Media: Prescriptions for Change. Lebanon, NH: University Press of New England.

Russo, M. (1995) The Female Grotesque: Risk, Excess and Modernity. London: Routledge.

Scully, J.L. (2008) Disability Bioethics: Moral Bodies, Moral Difference. New York: Rowman and Littlefield Publishers.

Scully, J.L. (2010) Hidden labor: Disabled/nondisabled encounters, agency and autonomy. International Journal of Feminist Approaches to Bioethics 3(2): 25-42.

Shakespeare, T. (1994) Cultural representation of disabled people - dustbins for disavowal. Disability \& Society 9(3): 283-299.

Shakespeare, T. (1996) Disability, identity and difference. In: C. Barnes and G. Mercer (eds.) Exploring the Divide: Illness and Disability. Leeds, UK: The Disability Press, pp. 94-113.

Shakespeare, T. (2006) Disability Rights and Wrongs. Abingdon, UK: Routledge.

Sheehan, J.G. (1968) Stuttering as a self-role conflict. In: H. Gregory (ed.) Learning Theory and Stuttering Therapy. Evanston, IL: Northwestern University Press.

Sheehan, J.G. (ed.) (1970) Role-conflict theory. In: Stuttering: Research and Therapy. New York: Harper \& Row, pp. 2-34.

Shildrick, M. (2002) Embodying the Monster: Encounters With the Vulnerable Self. London: Routledge.

Shildrick, M. (2009) Dangerous Discourses of Disability, Subjectivity and Sexuality. London: Palgrave Macmillan.

Shildrick, M. (2012) Critical disability studies: Rethinking the conventions for the age of postmodernity. In: N. Watson, A. Roulstone and C. Thomas (eds.) Routledge Handbook of Disability Studies. London: Routledge, pp. 30-41.

Silk, M.L., Francombe, J. and Bachelor, F. (2011) The biggest loser: The discursive constitution of fatness. Interactions: Studies in Communication \& Culture 1(3): 369-389.

Skeggs, B. (1997) Formations of Class and Gender. London: Sage.

Skeggs, B. (2001) The toilet paper: Femininity, class and mis-recognition. Women's Studies International Forum 24(3/4): 295-307.

Smith, G. (2000) Erving Goffman. Abingdon, UK: Routledge.

Sparkes, A.C. and Smith, A.M.A. (2002) Sport, spinal cord injury, embodied masculinities, and the dilemmas of narrative identity. Men and Masculinities 4(3): 258-285.

Titchkosky, T. (2000) Disability studies: The old and the new. Canadian Journal of Sociology-Cahiers Canadiens De Sociologie 25(2): 197-224.

Tremain, S. (2002) On the subject of impairment. In: M. Corker and T. Shakespeare (eds.) Disability/ Postmodernity: Embodying Disability Theory. London: Continuum, pp. 32-47.

UPIAS. (1975) Fundamental Principles of Disability. London: The Union of the Physically Impaired Against Segregation. 
Waskul, D.D. and Vannini, P. (eds.) (2006) Introduction: The body in symbolic interaction. In: Body/embodiment: Symbolic Interaction and the Sociology of the Body. Aldershot, UK: Ashgate, pp. $1-18$.

Watson, N., Roulstone, A. and Thomas, C. (eds.) (2012) Routledge Handbook of Disability Studies. London: Routledge.

Wendell, S. (1996) The Rejected Body: Feminist Philosophical Reflections on Disability. London: Routledge.

Williams, G. (2001) Theorizing disability. In: G.L. Albrecht, K.D. Seelman and M. Bury (eds.) Handbook of Disability Studies. London: Sage, pp. 123-143.

(c) This work is licensed under a Creative Commons Attribu-
tion 3.0 Unported License. To view a copy of this license,
visit http://creativecommons.org/licenses/by/3.0/ 